\author{
KS. WALDEMAR GRACZYK* \\ Warszawa, Polska
}

ORCID ID oooo-0002-8057-8368

\title{
MAZOWSZE W PRZEPOWIADANIU PRYMASA STEFANA WYSZYŃSKIEGO
}

\begin{abstract}
Streszczenie: Jednym z przystanków budzenia wiary narodu, świadomości człowieka wolnego i odpowiedzialnego, tworzącego historię na fundamencie prawa i moralności Dekalogu, było Mazowsze. Prymas wielokrotnie, przy różnych okazjach odwiedzał Płock. Niósł słowo, które jak biblijne ziarno miało padać na glebę ludzkich serc i przynosić owoce. Kardynał Stefan Wyszyński po raz pierwszy jako Prymas przybył do Płocka pod koniec 1961 roku, aby uczestniczyć w uroczystościach pogrzebowych biskupa płockiego Tadeusza Pawła Zakrzewskiego (zm. 26 listopada). Potem wielokrotnie przybywał jeszcze do historycznej stolicy Mazowsza - 4 lutego 1962 roku konsekrował w płockiej katedrze biskupa Jana Wosińskiego; 12-13 listopada 1966 roku uczestniczył w Płocku w uroczystościach millenijnych; 16 kwietnia 1968 roku wygłosił kazanie w płockiej katedrze z okazji 50-lecia działalności Zgromadzenia Sióstr Pasjonistek, a zwłaszcza wziął udział w uroczystych obchodach jubileuszu 9oo-lecia istnienia diecezji płockiej, które miały miejsce w niedzielę 1 czerwca 1975 roku. To, co Prymas Polski kardynał Stefan Wyszyński mówił na Mazowszu Płockim i o Mazowszu, znalazło swoje dopełnienie w słowach św. Jana Pawła II, wypowiedzianych w dniu 7 czerwca 1991 roku podczas pobytu w Płocku: „Płock głęboko wrósł się w dzieje Polski i w dzieje Kościoła”. Podkreślał przez to rolę tego miasta, stolicy historycznego Mazowsza, w tysiącletniej historii naszej Ojczyzny. Mówił, że Mazowsze zajmuje wysokie miejsce w budowaniu państwa i Kościoła. Przywołując ważne dla Mazowsza postacie, wskazywał zawsze na wartości, których były one nośnikami, a które są ponadczasowe.
\end{abstract}

Słowa kluczowe: Mazowsze, Płock, Wyszyński, Millenium, Kościół.

* Ks. Waldemar Graczyk, Instytut Historii Uniwersytetu Kardynała Stefana Wyszyńskiego w Warszawie; e-mail: w.graczyk@uksw.edu.pl. 


\section{Wprowadzenie}

Wielokrotnie na duszpasterskim szlaku kardynała Stefana Wyszyńskiego znajdowało się Mazowsze. Ten region o wczesnośredniowiecznych tradycjach osadniczych i dogodnym położeniu, czego przejawem są szlaki handlowe wraz z wielkim szlakiem wodnym, przy którym powstawały takie ośrodki, jak Kraków i Płock, nierozdzielnie łączy swoje dzieje z dziejami Polski i Kościoła. Z pierwszymi władcami piastowskimi, których groby znajdują się w płockiej katedrze, Władysławem Hermanem i jego synem Bolesławem Krzywoustym, którzy przeprowadzali Polskę przez trudny okres przełomu XI i XII stulecia. Z Kościołem, gdzie pod koniec XI wieku powstała diecezja - nazwana początkowo mazowiecką. Te doświadczenia przeszłości wyrażały przez wieki dwie budowle, katedra i zamek książąt mazowieckich, umiejscowione naprzeciw siebie na wzgórzu tumskim w Płocku (Samsonowicz 1989, s. 146; Graczyk 2011, kol. 850-862; Dlugossii, wyd. Dąbrowski 1964, s. 179-180). Opinie o powstaniu biskupstwa relacjonuje Kumor (1968); List Grzegorza VII papieża do Bolesława Śmiałego roku 1075, wyd. Bielowski 1960; Gieysztor 1994, S. 100-101.

Prymas Tysiąclecia kardynał Stefan Wyszyński miał świadomość splecionych losów państwa polskiego i Kościoła, dlatego w miejscach, do których przybywał jako pasterz Kościoła polskiego, nawiązywał zawsze do przeszłości, kultury i osób, które były twórcami dziejów. Jednym z przystanków budzenia wiary narodu, świadomości człowieka wolnego i odpowiedzialnego, tworzącego historię na fundamencie prawa i moralności Dekalogu, było Mazowsze.

\section{Okoliczności przybycia kardynała Stefana Wyszyńskiego do Płocka}

Prymas wielokrotnie, przy różnych okazjach, odwiedzał Płock. Niósł słowo, które jak biblijne ziarno miało padać na glebę ludzkich serc i wydawać owoce. Kardynał Stefan Wyszyński po raz pierwszy jako Prymas przybył do Płocka pod koniec 1961 roku, aby uczestniczyć w uroczystościach pogrzebowych biskupa płockiego Tadeusza Pawła Zakrzewskiego (zm. 26 listopada). Potem wielokrotnie przybywał jeszcze do historycznej stolicy Mazowsza - 4 lutego 1962 roku konsekrował w płockiej katedrze biskupa Jana Wosińskiego; 12-13 listopada 1966 roku uczestniczył w Płocku w uroczystościach millenijnych; 16 kwietnia 1968 roku, wygłosił kazanie w płockiej katedrze z okazji 50-lecia działalności Zgromadzenia Sióstr Pasjonistek, a zwłaszcza wziął udział w uroczystych obchodach jubileuszu 9oo-lecia istnienia diecezji płockiej, w niedzielę 1 czerwca 1975 roku. Teksty wystąpień w czasie wizyt Prymasa Wyszyńskiego w Płocku były drukowane w lokalnym periodyku "Miesięcznik Pasterski Płocki” (zob. nr 1/1962, s. 1-29; 5/1962, s. 129-148; 11/1966, s. 245-261; 8/1968, s. 176-189; 11/1975, s. 401-415). Przemówienie milenijne, wygłoszone 12 listopada 1966 roku w Płocku, zostało wydrukowane w publikacji, w której 
zebrano przemówienia Prymasa. Jej tytuł brzmi: Z rozważań nad kulturą ojczysta (Poznań-Warszawa 1979).

\section{Znaczenie Płocka i Mazowsza w nauczaniu Prymasa}

Historyczna i kulturowa rola Mazowsza jako dzielnicy stanowiącej integralną część państwa Polskiego i jej wkład w kulturowo-religijny rozwój Polski wybrzmiały szczególnie w dwóch przemówieniach Prymasa: w czasie uroczystości milenijnych w 1966 roku i podczas jubileuszu diecezji w 1975 roku. Do treści tych dwóch przemówień ograniczę swoje przedłożenie.

Swoistą zapowiedzią myśli o roli Płocka i Mazowsza w dziejach Narodu i Kościoła, którą Prymas rozwinie podczas uroczystości milenijnych, były słowa wypowiedziane podczas mszy św. w czasie konsekracji biskupa Jana Wosińskiego, jaka miała miejsce 4 lutego 1962 roku. Podkreślając, iż Mazowsze, niosąc przez dzieje światło wiary, przyczyniało się do budowania jedności Narodu, w kazaniu wygłoszonym w płockiej katedrze Prymas powiedział: „Są trzy miasta - mówił Prymas - które od chłopięcych lat robiły na mnie największe wrażenie, to: Kruszwica, Gniezno i Płock. Jako mały chłopiec nawet ich osobiście nie znałem, ale samo ich wspomnienie robiło na mnie wielkie wrażenie. Dlaczego? Bo wydawało mi się, że z tymi nazwami wiązało się zawsze to, co było sercem i duchem idącej przez wieki Polski. Tak myślę do dziś, chociaż dużo w swym życiu pod różowałem, i wiele miast widziałem, dawne wrażenia zostały w moim sercu. Szczególnie teraz, gdy wracamy do przeszłości historycznej, na progu Tysiąclecia Narodu i Kościoła te trzy nazwy - Kruszwica, Gniezno, Płock, żywo przemawiają do wyobraźni dziejowej naszego społeczeństwa. Byłoby rzeczą niezmiernie doniosłą, aby wasze miasto, które jak wiele innych ulega przemianom społecznym, w wyniku rozwoju gospodarczego, mogło nadal zachować swą jednoczącą moc, krzepiąc ducha polskiego, przedziwną siłą wiary i umacniając jedność religijną, której zawsze przodowało" („Miesięcznik Pasterski Płocki” 1962, nr 5, s. 139).

Te słowa oddają głębokie przekonanie Prymasa, że Sacerdotium i imperium to kluczowe pojęcia dla zrozumienia dziejów Polski. Nie wyobrażano sobie istnienia przez wieki państwa bez fundamentu w postaci religii wraz z ukształtowaną organizacją kościelną. W szczytowym okresie polskiego średniowiecza (wieki XIII-XV) religia (mam na myśli chrześcijańską wraz z jej wyznaniem rzymskim) współtworzyła państwo w sensie bytu politycznego, choćby przez aktywną działalność - również polityczną - episkopatu metropolii gnieźnieńskiej, a od XV wieku - lwowskiej; miała również współudział w kształtowaniu fundamentu prawa państwowego; jak również szeroko pojętej kultury i działalności społecznej.

To zagadnienie wspólnoty dziejów, myśli państwa i Kościoła podjął kardynał Stefan Wyszyński podczas przemówienia w płockiej katedrze, wygłoszonego 12 listopada 1966 roku, w czasie obchodów Milenium Chrztu Polski. Powiedział wówczas: „Stojąc w tej romańskiej bazylice [...] pamiętamy, że podobnie jak 
w Gnieźnie, Poznaniu, Krakowie i Warszawie, tak i tutaj w Płocku, stoimy wobec grobów królewskich. Stajemy wobec majestatu Rzeczypospolitej chrześcijańskiej, w obliczu mocy, która zaślubiła w ziemi naszej Kościół i Naród [...]. Patrzymy tu na ślady owocnego i trwałego współdziałania Kościoła i Narodu, żyjącego kulturą chrześcijańską, którą w ziemi polskiej tworzył społem Kościół i Naród ochrzczony. Nasza cześć potęguje się na wspomnienie młodzieńczej postaci syna ziemi mazowieckiej, świętego Stanisława Kostki [...]” („Miesięcznik Pasterski Płocki” 1966, nr 11, s. 245-246).

Tymi słowami zwracał Prymas uwagę na narodową tożsamość Polaków, swymi korzeniami sięgającą właśnie wydarzenia chrztu Polski. Z tego wydarzenia, jak ze źródła, wypływały wartości duchowe, o które nieustannie naród, podczas zawiłych losów swojej historii musiał walczyć. Zwycięstwo przychodziło zawsze przez silny związek z Bogiem wynikający z głębokiej wiary. To były piękne, choć nieraz bolesne karty naszej historii. Tenże sam Prymas dnia 1 czerwca 1975 roku powiedział: „Jako Naród odznaczający się poczuciem wysokiej kultury utrzymujemy ciągłość historyczną z przeszłością, świadomi, że to przeszłość zrodziła teraźniejszość i jest gwarantem zdrowego rozwoju przyszłości. Naród bez dziejów jest narodem ubogim; naród, który ma dzieje i te szanuje, jest narodem, który wierzy w swoją przyszłość. Jak mały krzew rozwija się w drzewo i potężnieje w dęby, tak również i dzieje narodu muszą mieć tworzywo. Tym tworzywem dla dziejów narodu ku przyszłości jest nasza przeszłość i teraźniejszość, a szacunek dla przeszłości jest znakiem dojrzałości duchowej i kulturalnej Narodu" (Śniegocki 1976).

W dzieje Płocka i Mazowsza wpisali się znakomici biskupi, którzy swoją głęboką wiarą dawali dowód świadectwa służby Chrystusowi, będącemu Panem Dziejów. Ogromne zaangażowanie biskupów płockich wypływało z poczucia odpowiedzialności za Rzeczpospolitą i świadomości roli politycznej, jaką mieli do spełnienia. Wielu z nich (Andrzej Noskowski, Karol Ferdynand Waza, Stanisław Łubieński, Wojciech Baranowski itd.), zanim zostali biskupami płockimi, pełniło ważne funkcje, czy to na rzecz monarchy, czy też państwa. Będąc już biskupami płockimi, otrzymywali bardzo delikatne i trudne misje dyplomatyczne, np. Piotr Dunin Wolski w 1579 roku z ramienia monarchy został wytypowany na posła obediencyjnego do Stolicy Apostolskiej, gdzie przebywał do 1582 roku. Nie była to jego pierwsza misja dyplomatyczna, w latach 1561-1573 z mandatu monarchy przebywał bowiem w Hiszpanii, w sprawie tzw. sum neapolitańskich, początkowo w randze regenta, a następnie internuncjusza. Starał się uzyskać egzekucję praw Zygmunta Augusta do spadku po matce (królowej Bonie), zagarniętego przez Filipa II (Volsciana. Katalog renesansowego księgozbioru Piotra Dunin - Wolskiego, biskupa płockiego, 1999, s. 5). Analogicznie, z misją dyplomatyczną w Rzymie przebywał w latach 1595-1596 biskup Wojciech Baranowski. Jako poseł królewski prowadził z papieżem Klemensem VIII rozmowy w sprawie utworzenia ligi antytureckiej (Słownik Biograficzny Polski (hasło: Baranowski Wojciech, oprac. Strzelecki 1989). Do rozmów w sprawie utworzenia ligi antytureckiej został wyznaczony inny biskup płocki, 
Stanisław Dąbski, który w 1681 roku wszedł w skład delegacji polskiej prowadzącej rozmowy w tej sprawie. Warto zaznaczyć, że biskup ten czynnie zaangażował się w czasie odsieczy wiedeńskiej, wystawiając własnym kosztem chorągiew husarską (Słownik Biograficzny Polski (hasło: Dąbski Stanisław, oprac. Piwarski 1989).

Mając świadomość szczególnej roli płockiego episkopatu, tak religijnej, kulturowej, jak i politycznej, szczególny hołd wdzięczności wielokrotnie składał Prymas dwóm płockim biskupom: arcybiskupowi Antoniemu Julianowi Nowowiejskiemu (1909-1941) (Graczyk, Krysztofiak 2008, s. 7), który bierzmował przyszłego Prymasa w Andrzejewie w 1913 roku oraz biskupowi Leonowi Wetmańskiemu (1928-1941) (Grzybowski 1973, s. 311-328) - zamęczonym w obozie koncentracyjnym podczas ostatniej straszliwej wojny. W ofierze ich życia streszcza się zwycięstwo wiary Mazowsza. Ci dwaj płoccy męczennicy, wyniesieni na ołtarze 13 czerwca 1999 roku, są „kwiatem zwycięskim na wielkim kurhanie dziejowym, sypanym przez wiarę, miłość i pracę duchowieństwa, biskupów i ludu Bożego diecezji płockiej. [...] Dziękujemy im, że bez wahania dali przykład wierności Bogu, Kościołowi i narodowi. Leżący na ziemi, kopany przez gestapowców staruszek, Biskup Antoni, wiedział, że jest to jego obowiązek, że to największa jego chwała - dla imienia Chrystusowego zniewagę cierpieć. Zostawił przykład nam, kapłanom, jak mamy służyć ludowi aż do oddania życia. I Wam [...] dał przykład jak przezwyciężać zagrożenia wiary Chrystusowej, moralności chrześcijańskiej i kultury religijno-narodowej. Jest to prawdziwy dorobek dziejowy waszej diecezji - podkreślał kardynał Stefan Wyszyński w płockiej katedrze 1 czerwca 1975 roku” („Miesięcznik Pasterski Płocki" 1975, nr 11, s. 411). Takie zachowanie i postawa biskupów płockich $\mathrm{w}$ działdowskim obozie stanowiła podporę i umocnienie dla przebywających tam więźniów. Określona jako postawa równowagi ducha, niezależna od warunków życia, charakteryzuje tylko te osoby, które dzięki żarliwej wierze, jak na mocnym fundamencie, wznoszą się ku szczytom świętości (Graczyk 1999, s. 70).

\section{Osoba ludzka w płockich przemówieniach Prymasa}

Ten wątek poświęcenia, trudu i ofiary, który mocno wybrzmiał w Płocku w 1975 roku, był niejako rozwinięciem i ukonkretnieniem myśli podjętej kilka lat wcześniej - 16 czerwca 1968 roku. To piękne połączenie krzyża, cierpienia z dziejami narodu miało miejsce podczas jubileuszu 50-lecia istnienia Zgromadzenia Sióstr Pasjonistek, w których istotę powołania wpisane jest rozważanie tajemnicy krzyża Chrystusowego. Każda droga życia naznaczona jest trudem i ofiarą. Wielu na tej drodze się buntuje, gdyż nie widzi jego sensu. By to zrozumieć, Prymas przywołał w przemówieniu 16 czerwca 1968 roku, wygłoszonym w katedrze płockiej, obraz historii narodu, „[...] który silny wiarą w potęgę zbawczą Krzyża, (nigdy) się nie załamał. Chociaż na początku II wojny światowej w różnych stolicach krzyczano - koniec Polski - nie było to w zamiarach Bożych. Bóg krzepił, umacniał, dodawał sił. Nie ma tych co krzyczeli. Naród jest, pracuje spokojnie i ufa, szczęśliwy, że 
umie patrzeć w Krzyż, rozważać mękę Chrystusową i czerpać moce dla swojego codziennego trudu. Mijają epoki, rozpadają się systemy, ale ciągle aktualny pozostaje obraz Boga - Człowieka na krzyżu. Doświadczenie cierpienia i poświęcenia może być tylko zrozumiałe w kontekście krzyża Chrystusowego. Współczesnemu człowiekowi, który ma tyle nadziei na spokojniejsze i lepsze ułożenie życia na ziemi, znak Krzyża jest może mniej potrzebny. Wszyscy tęsknią do takiego układu stosunków międzyludzkich, aby mniej było męki, a więcej miłości, jedności i pokoju. Cała nauka współczesna zmierza do wyeliminowania cierpienia i męki ludzkiej. Wiedza lekarska zmaga się z tym zadaniem i budzi nadzieję, że ograniczy zakres cierpienia” („Miesięcznik Pasterski Płocki” 1968, nr 8, s. 187-188).

Prymas miał świadomość, że uszlachetniona przez trud, cierpienie i ofiarę osoba w pełni dostrzega swoją godność i wolność. Prawda o wielkiej wartości osoby ludzkiej stanowiła dla Prymasa Tysiąclecia fundament ładu społecznego na świecie.

O ludzkiej godności i prawach osoby ludzkiej przypomniał podczas uroczystości milenijnych w płockiej katedrze, podczas uroczystej sumy odprawionej w niedzielę 13 listopada 1966 roku: „Wszelka walka z podstawowymi prawami osoby ludzkiej jest szkodliwa nie tylko dla Kościoła, ale dla Narodu i Państwa. Godzą się na to wszyscy współcześni, w obecnym kierunku rozwojowym myśli ludzkiej” (mps w zbiorach Instytutu Prymasowskiego Ślubów Narodu, bez sygn., s. 9). Prymas - choć nie wprost - nawiązał do idei, która dzięki pochodzącemu z Mazowsza Pawłowi Włodkowicowi na początku XV wieku skupiała uwagę średniowiecznej Europy. Na soborze w Konstancji (1414-1418) Paweł Włodkowic powiedział ówczesnym przedstawicielom chrześcijańskiej potęgi, „że nie godzi się nawracać mieczem, że sumienie ludzkie i jego wolność jest ważniejsza ponad wszystko, że wolność przekonania i wyznania - nawet błędu - bardziej odpowiada kulturze ludzkiej, aniżeli przemoc i przemocą narzucana prawda. A cóż dopiero kłamstwo, fałsz, propaganda i najrozmaitsze złudzenia, w imię których odbiera się ludziom prawdę Bożą, by na jej miejsce postawić złudę opinii ludzkiej. Cóż dopiero metody przezwyciężania Boga Żywego, by na jego miejsce stawiać bogów fałszywych. W ten sposób - zdaniem kardynała Stefana Wyszyńskiego - Paweł Włodkowic pokazał wielką godność każdego człowieka i narodu, który choćby maleńki i słaby, ma prawo do życia. Podniósł również na szczyty godność Chrystusowej Ewangelii, którą trzeba przepowiadać nie mieczem, ale miłością i pokojem” („Miesięcznik Pasterski Płocki” 1966, nr 11, s. 255-256; Ehrlich 1954, s. 56; Silnicki 1962, s. 82; Wesołowska 1997, s. 100). Ta prawda o ludzkiej wolności i godności wypowiedziana na wzgórzu tumskim w czasie Milenium Chrztu Polski jest najważniejszym przesłaniem wynikającym z nauczania i życia Prymasa Tysiąclecia.

\section{Zakończenie}

Podsumowując, należy zaznaczyć, że słowa wypowiedziane przez Prymasa Polski kardynała Stefana Wyszyńskiego na Mazowszu Płockim i o Mazowszu wynikały z głębokiego przekonania o roli tego regionu w dziejach Polski, wyjątkowej pozycji 
stolicy historycznego Mazowsza, tj. Płocka, i to nie tylko w okresie niezależności Mazowsza od Korony (do 1526 roku), ale w tysiącletniej historii Polski. Prymas Stefan Wyszyński, mówiąc o Mazowszu, podkreślał zawsze jego wysokie miejsce w budowaniu Państwa i Kościoła. Przywołując ważne dla Mazowsza postacie, wskazywał zawsze na wartości, których były one nośnikami, a których oddziaływanie jest ponadczasowe. Miał świadomość przemian, jakim dzielnica ta podlegała na przestrzeni wieków, jej wkładu w szeroko rozumianą kulturę narodową. Jego słowa, wypowiadane na Mazowszu, zawsze ukazywały szerszy kontekst dziejowy, a przede wszystkim miały na celu umocnienie wiary ludu Mazowsza przez podkreślanie kontekstu historycznego i kulturowego.

\section{Bibliografia}

\section{Źródła drukowane}

Dlugossii I. (1994). Annales seu Cronicae Incliti Regni Poloniae, lib. 1-2. Warszawa: wyd. J. Dąbrowski.

Kazanie Prymasa Polski kardynała Stefana Wyszyńskiego wygtoszone w katedrze płockiej, 4 lutego 1962 roku (1962). „Miesięcznik Pasterski Płocki”, nr 5, s. 129-148.

Kazanie Prymasa Polski kardynała Stefana Wyszyńskiego wygłoszone w katedrze płockiej, 12 listopada 1966 roku (1966). „Miesięcznik Pasterski Płocki”, nr 11, s. 245-261.

Kazanie Prymasa wygłoszone w czasie sumy millenijnej w katedrze płockiej, 13 listopada 1966 roku (mps, Instytut Prymasowski Ślubów Narodu, bez sygn.).

List Grzegorza VII papieża do Bolesława Śmiałego roku 1075 (1960). W: Monumenta Poloniae Historica. T. 1. Warszawa: wyd. A. Bielowski, s. 367-368.

Słowa Prymasa wygłoszone w katedrze płockiej, 16 czerwca 1968 roku (1968). „Miesięcznik Pasterski Płocki”, nr 8, s. 176-189.

Słowa Prymasa wygłoszone w katedrze płockiej, 1 czerwca 1975 roku (1975). „Miesięcznik Pasterski Płocki”, nr 11, s. 401-415.

Volsciana. Katalog renesansowego księgozbioru Piotra Dunin-Wolskiego, biskupa płockiego (1999). Obrębki A. (oprac.). Kraków: Księgarnia Akademicka.

Wyszyński S. (1979). Z rozważań nad kulturą ojczysta. Poznań-Warszawa, s. 99-106.

\section{Literatura przedmiotu}

Gieysztor A. (1994). Trzy stulecia najdawniejszego Mazowsza (połowa X-połowa XIII w.). W: Gieysztor A., Samsonowicz H. (red.). Dzieje Mazowsza do 1526 roku. Warszawa: Wydawnictwo Naukowe PWN, s. 85-132.

Graczyk W. (1999). Obóz przejściowy w Działdowie miejscem męczeńskiej śmierci arcybiskupa A.J. Nowowiejskiego i biskupa L. Wetmańskiego. „Światło Narodów”, $\mathrm{nr}$ 2, s. 63-70. Graczyk W. (2011). Płocka Diecezja. W: Encyklopedia Katolicka. T. 15. Lublin: TN KUL, kol. $850-862$. 
Graczyk W. (2015). Stosunki wyznaniowe na Mazowszu. Duchowieństwo mazowieckie w działalności Kościoła polskiego. W: Tyszkiewicz J. (red.). Dzieje Mazowsza lata 15271794. Pułtusk: Akademia Humanistyczna, s. 311-358.

Graczyk W., Krysztofiak P. (2008). Zobaczyć Chrystusa w człowieku. Troska o potrzebujacych na podstawie listów pasterskich bł. Abpa Antoniego Juliana Nowowiejskiego. Płock: Wydawnictwo Diecezjalne.

Grzybowski M.M. (1973). Biskup Leon Wetmański, sufragan płocki 1886-1941. „Miesięcznik Pasterski Płocki”, nr 8, s. 311-328.

Kumor B. (1968). Granice metropolii i diecezji polskich. „Archiwa Biblioteki i Muzea Kościelne", nr 19, s. 271-351.

Piwarski K. (1939-1946). Dąbski Stanisław. W: Polski Słownik Biograficzny. T. 5, s. 37.

Samsonowicz H. (1989). Przesłanki tworzenia się narodu mazowieckiego na przełomie XV

i XVI wieku. W: Narody, jak powstawały i wybijały się na niepodległość. Warszawa:

Wydawnictwo Naukowe PWN, s. 146-153.

Strzelecki A. (1935). Baranowski Wojciech. W: Polski Słownik Biograficzny. T. 1, s. 287-288. Śniegocki J. (1976). Uroczystości 9oo-lecia diecezji płockiej. „Studia Płockie”, nr 4, s. 265-275.

\section{MAZOVIA IN PRIMATE STEFAN WYSZYŃSKI'S TEACHING}

Abstract: Mazovia was one of the important points on the national path of faith as well as on the path of awakening awareness of a free and responsible human being who makes history on a basis of the law and morality of the Ten Commandments. Primate Stefan Wyszyński many times visited Płock. He delivered sermons which, as biblical grain, were to fall on the soil of human hearts and bear fruits. Cardinal Wyszyński came to Płock for the first time as the primate of Poland at the end of 1961 to participate in a funeral of the bishop of Płock Tadeusz Paweł Zakrzewski (+26.11.1961). In the next years, he has been returning to the historical capital of Mazovia many times. On February 4, 1962, the Primate consecrated bishop Jan Wosiński in the Płock Cathedral. Furthermore, the Primate took part in solemn celebrations of Millenium in Płock (November 12-13, 1966). Afterwards, he delivered a sermon in the Płock Catherdal on 5oth anniversary of the Order of Sisters of Our Lord Jesus Christ's Passion. Most importantly, the Primate participated in a solemn festivity of gooth anniversary of the Płock Diocese (on Sunday, June 1st, 1975). A message of the Cardinal Wyszyński's words and sermons delivered in Płock was in full accordance with Saint Pope John Paul II's speech given on June 7th, 1991, during his visit in Płock: "Płock is deeply rooted in the Polish history and in the history of the Church". By these words the Pope highlighted a role of the city of Płock as the capital of Mazovia, in the history of Poland. Accordingly, Primate Stefan Wyszyński was highlighting a high position of Płock in supporting the State and the Church. In his speeches, he pointed out important figures to narrate about timeless values.

Keywords: Mazovia, Płock, Wyszyński, Millenium, Catholic Church. 